\title{
A new clinical sign probably associated to left hemiplegia with left hemineglect syndrome: the crossed legs
}

\author{
Novo sinal clínico provavelmente associado a hemiplegia esquerda com heminegligência \\ espacial esquerda: as pernas cruzadas
}

Rodrigo Bazan, Thiago Fernandes, Gabriel Braga, Gustavo Luvizutto, Luiz Resende

\begin{abstract}
Objective: To describe a new clinical sign associated with left unilateral neglect syndrome (UNS) in patients with ischemic stroke. Method: Head computed tomography (CT) and National Institute of Health Stroke Scale were obtained in 150 patients with ischemic stroke. Those with right cerebral vascular lesions, left hemiplegia and right leg persistently crossed over the left were submitted to specific tests for UNS. The tests were also applied to 30 patients with right cerebral vascular lesions, left hemiplegia but without crossed legs. Results: From 9 patients with persistent tendency to cross the right leg over the left, UNS was detected in 8. One patient died before the clinical tests were applied. Of the 30 patients without the crossed legs, 20 had normal clinical tests for UNS and 10 had minimal alterations, not sufficient for the diagnosis of UNS. Conclusion: The right leg crossed over the left may represent a new neurological semiotic sign associated with left hemiplegia and left UNS.
\end{abstract}

Keywords: crossed legs, hemiplegia, spatial neglect syndrome.

\section{RESUMO}

Objetivo: Descrever um novo sinal clínico associado à síndrome de negligência unilateral (SNU) em pacientes com acidente vascular cerebral isquêmico (AVCi). Método: Em 150 pacientes com acidente vascular cerebral isquêmico, foram realizadas tomografias de crânio e aplicada a National Institute of Health Stroke Scale. Aqueles pacientes com lesões vasculares à direita, hemiplegia esquerda e perna direita persistentemente cruzada sobre a esquerda, foram submetidos a testes específicos para SNU. Trinta pacientes também com lesões vasculares à direita, hemiplegia esquerda, porém sem evidências de permanecerem com as pernas cruzadas, foram submetidos aos mesmos testes clínicos. Resultados: Entre 150 pacientes com AVCi, 9 apresentaram lesão vascular cerebral à direita, hemiplegia esquerda e tendência em permanecer com a perna direita cruzada sobre a esquerda. Em 8 deles, testes específicos realizados nos primeiros dias de internação, confirmaram SNU à esquerda. Um paciente morreu antes que os testes pudessem ser aplicados. Dos 30 pacientes que não cruzaram as pernas, os testes foram normais em 20. Dez pacientes apresentaram alterações mínimas, insuficientes para o diagnóstico de SNU. Conclusão: A perna direita cruzada sobre a esquerda pode representar um novo sinal semiológico associado à hemiplegia esquerda e SNU à esquerda.

Palavras-chave: pernas cruzadas, hemiplegia, síndrome de negligência espacial.

Several text books about neurological examination do not describe crossed legs as a clinical semiotic sign in the acute and sub-acute phase of a stroke ${ }^{1,2,3}$. Unilateral spatial neglect syndrome (UNS) is a common finding in patients with right brain stroke $e^{4,5,6,7}$. Rémi et al. ${ }^{8}$ described 34 patients with stroke and crossed legs, but no association was made with UNS. In recent years we have observed patients with acute stroke in the right cerebral hemisphere who presented alterations in consciousness, left hemiplegia, and the right leg crossed over the left. In almost all cases, we were able to demonstrate left UNS during some phase of clinical evolution. As far as we know, this is the first clinical description that associates crossed legs with left hemiplegia and left UNS.

\section{METHOD}

One hundred and fifty consecutive patients with ischemic stroke admitted to the University Hospital from the Botucatu School of Medicine (UNESP) from 2011 to 

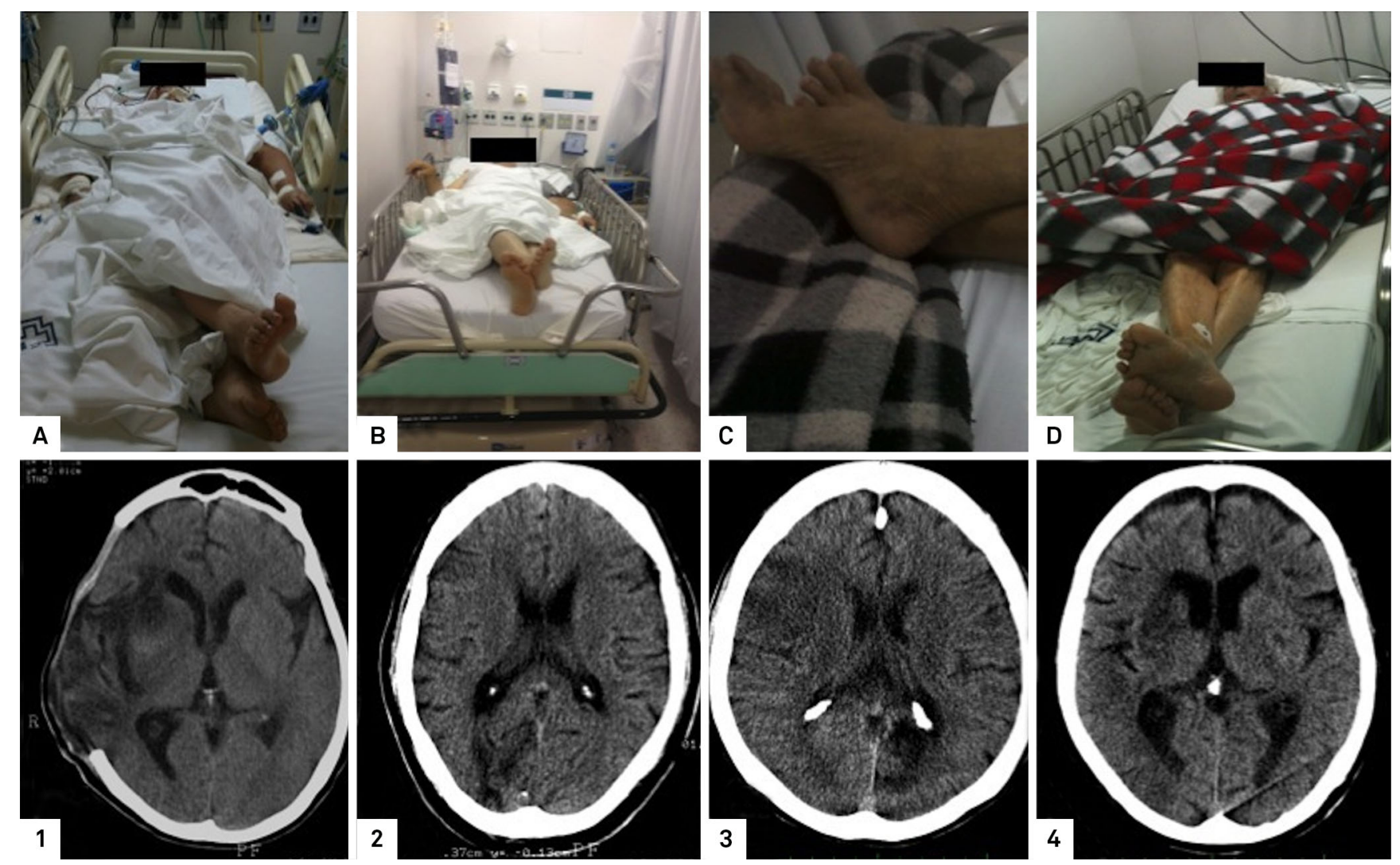

Figure 1. Patients 1, 2, 3 and 4, with right leg crossed over the left and their respective CT scans showing right ischemic stroke.
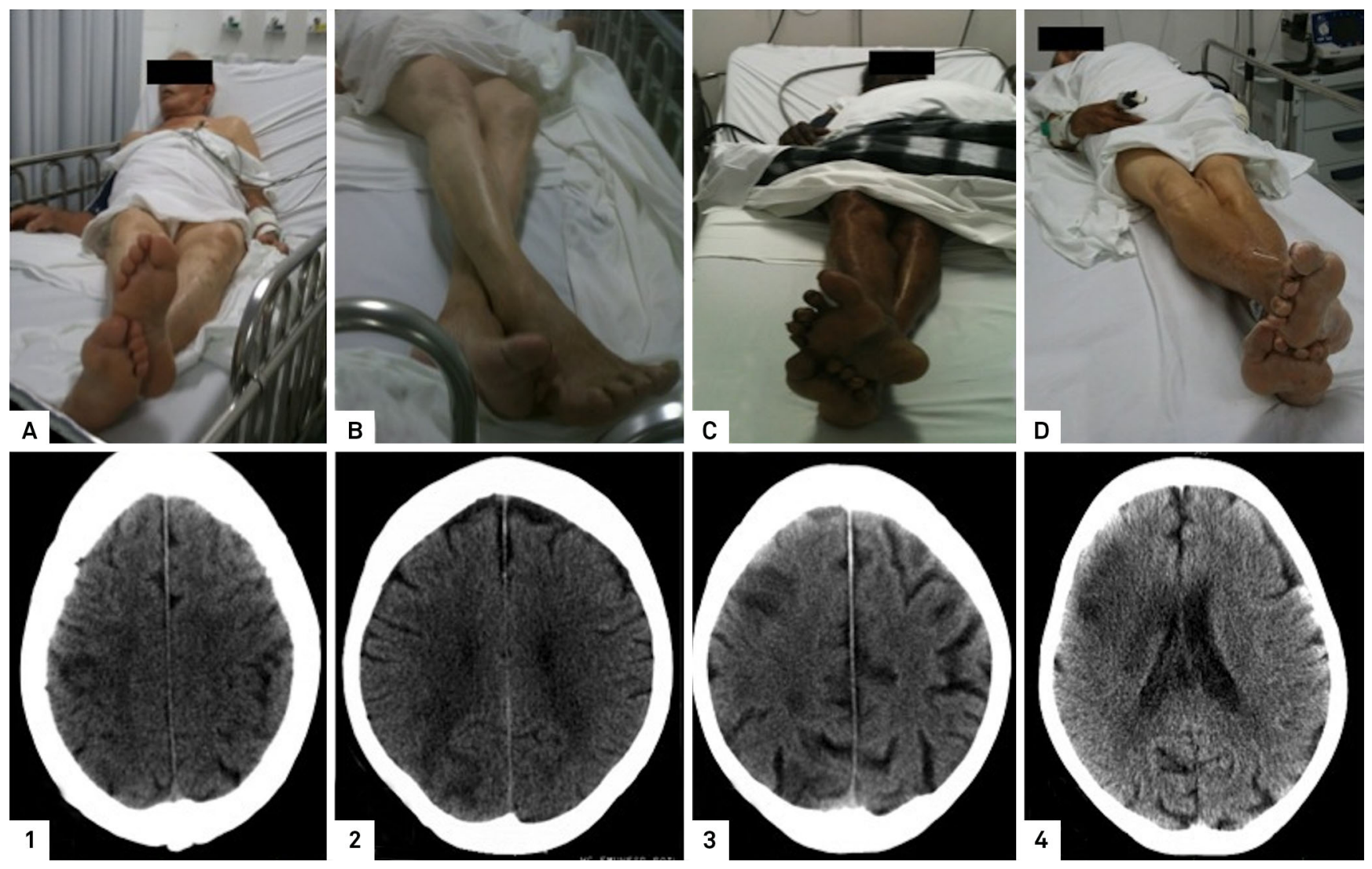

Figure 2. Patients 5, 6, 7 and 8 with right leg crossed over the left and their respective CT scans showing right ischemic stroke. 
2012 were analysed. The National Institutes of Health Stroke Scale (NIHSS) and CT scan were obtained at admission. Patients with right vascular ischemic lesions, left hemiplegia and a persistent behaviour of crossing the right leg over the left, and another 30 random selected patients with right vascular ischemic lesions and left hemiplegia but without crossed legs were submitted to specific tests for UNS. Patients with previous neurological sequelae were excluded. Three different tests previously validated in normal volunteers were applied during the first few days after the stroke, namely Line Cancellation ${ }^{9}$, Line Bisection ${ }^{10}$, and Star Cancellation ${ }^{11}$. Only abnormality in all three tests was considered UNS. We were unable to perform UNS tests on one patient with crossed legs because his rapid deterioration. This study was approved by the Ethics Committee on Human Research of our University Hospital. Written informed consent was given by a close relative or a legal guardian.

\section{RESULTS}

Nine patients with right cerebral vascular lesions, left hemiplegia and persistent tendency to cross the right leg over the left were found.

All of them had not suffered any prior stroke and had been leading a normal life up to admission. The consciousness level varied among them. All 9 presented with the right leg crossed over the left, even in coma (Figures 1 and 2, with patients and their CT scans). This clinical sign was present for the majority of the time between admission and discharge. All presented frequent rubbing movements of the right leg over the left in the first 48 to 72 hours of clinical evolution. Eight presented left-hand side UNS during the recovery phase. UNS tests were not performed in one patient due to rapid deterioration.

Clinical data including risk factors for stroke are summarized in Table.

In 30 patients with right ischemic stroke and left hemiplegia but without crossed legs, the 3 tests were normal in 20, and showed minimal alterations in 10, not sufficient for the clinical diagnosis of UNS.

\section{DISCUSSION}

All nine patients presented varying degrees of motor and consciousness alterations after stroke in the right cerebral hemisphere, and at admission or during clinical evolution presented with the right leg crossed over the left (Figures 1 and 2). Left-hand side unilateral spatial neglect was detected in 8 of the 9 patients. Rémi et al. ${ }^{8}$ stated that the presentation of crossed legs suggests a good prognosis in cerebrovascular disease. One of our patients died. In our

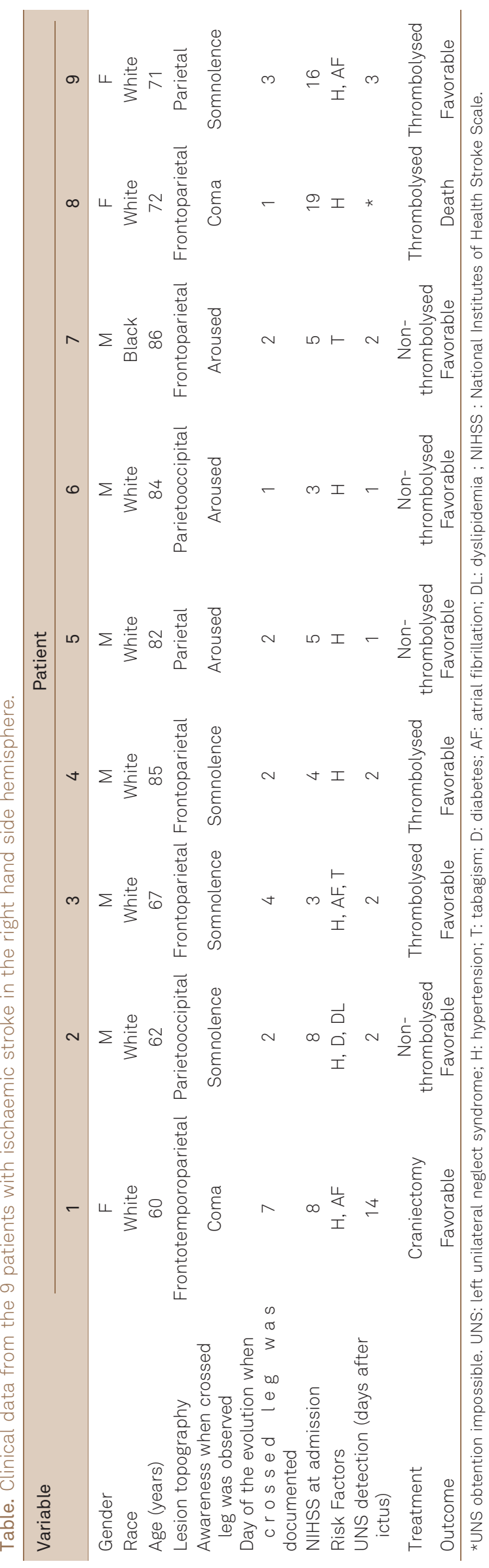


opinion, the prognosis in these patients is multifactorial, depending on factors such as age, lesion topography, injury extent, risk factors, etc. In a series of 93 patients, a bad prognosis was linked to the presence of superficial sensory disorders, depressive syndrome, and urinary incontinence. Hemineglect syndrome was not linked to the prognosis ${ }^{12}$.

Our descriptive casuistic is too small for considerations about the effects of either thrombolytic treatment or the risk factors.

It is impossible to detect UNS during coma, but frequent rubbing movements of the right leg over the left observed in the first days of the clinical evolution may match a different and not previously described form of anosognosia in patients with torpor or coma. If the left leg is not perceived or felt to be one's own limb, then abnormal rubbing movements could appear. The absence of the presentation of crossed legs in the control group enhances its association with UNS.

The right leg crossed over the left leg is simple and easy to detect, and may be of predictive value in UNS development. In conclusion, our patients presented with the right leg crossed over the left, which may represent a new neurological semiotic sign associated with left hemiplegia and hemineglect syndrome. Its clinical significance for a good or bad prognosis will be defined in future studies of hundreds of patients.

\section{References}

1. Déjerine JJ. Sémiologie des affections du système nerveux. Paris; Masson 1914:167-183.

2. Campbell WW. De Jongás neurological examination. $6^{\text {th }}$ ed. Philadelphia; Lippincott 2005

3. Posner JB, Saper CB, Schiff ND, Plum F. Plum and Posner's diagnosis of stupor and coma. $4^{\text {th }}$ ed. New York; Oxford University Press 2007.

4. Bowen A, McKenna K, Tallis RC. Reasons for variability in the reported rate of occurrence of unilateral spatial neglect after stroke. Stroke 1999;30:1196-2202.

5. Plummer P, Morris ME, Dunai J. Assessment of unilateral neglect. Physical Ther 2003;83:732-740.

6. Urbanski M, Angeli V, Bourlon C, et al. Néglicence spatiale unilatérale: une conséquence dramatique mais souvent négligée des lésions de l'hemisphère droit. Rev Neurol (Paris) 2007;162:305-322.

7. Vossel S, Weiss PH, Eschenbeck P, Saliger J, Karbe H, Fink GR. The neural basis of anosognosia for spatial neglect after stroke. Stroke 2012;43:1954-1956.
8. Rémi J, Pfefferkorn T, Owens RL, et al. The crossed leg sign indicates a favorable outcome after severe stroke. Neurology 2011:77:1453-1456.

9. Albert ML. A simple test of visual neglect. Neurology 1973;23:658-664.

10. Schenkenberg T, Bradford DC, Ajax ET. Line Bisection and unilateral visual neglect in patients with neurologic impairment. Neurology 1980;30:509-517.

11. Halligan PW, Burn JP, Marshall JC, Wade DT. Visuo-spatial neglect: qualitative differences and laterality of cerebral lesion. J Neurol Neurosurg Psychiatry 1992;55:1060-1068.

12. Petrilli S, Durufle A, Nicolas B, Pinel JF, Kerdoncuff V, Gallien P. Prognostic factors in the recovery of the ability to walk after stroke. $J$ Stroke Cerebrovasc Dis 2002;11:330-335. 